\title{
CONDITIONED MEDIUM FROM CULTURES OF EMBRYONIC NEURONS CONTAINS A HIGH MOLECULAR WEIGHT FACTOR WHICH INDUCES ACETYLCHOLINE RECEPTOR AGGREGATION ON CULTURED MYOTUBES ${ }^{1}$
}

\author{
ANNE E. SCHAFFNER ${ }^{2}$ AND MATHEW P. DANIELS \\ Laboratory of Biochemical Genetics, National Heart, Lung, and Blood Institute, National Institutes of Health, \\ Bethesda, Maryland 20205
}

Received June 1, 1981; Revised September 8, 1981; Accepted December 28, 1981

\begin{abstract}
The developmental mechanisms involved in the formation of stable arrays of postsynaptic neurotransmitter receptors near sites of neurotransmitter release are essentially unknown. However, several recent studies have shown that cells or tissues of neural origin produce macromolecular factors which induce an increase in the number of acetylcholine (ACh) receptors or the number of receptor aggregates on cultured embryonic myotubes.

We have tested primary cultures of embryonic neurons and other cell types for the release of an ACh receptor aggregation factor. Conditioned medium from the cultures was applied to cultures of embryonic rat myotubes for 1 day; $\mathrm{ACh}$ receptors on the myotubes were stained with tetramethylrhodamine-labeled $\alpha$-bungarotoxin and $\mathrm{ACh}$ receptor aggregation activity, defined as the change in the number of receptor aggregates per myotube, was assayed. Aggregation activity with a molecular weight $\geq 50,000$ was released by cultures of neurons from sympathetic ganglia, dorsal root ganglia, spinal cord, and cerebellum. Little or no activity was released by glial or other non-neuronal cultures. Release of aggregation activity by different neuronal cell types varied by up to an order of magnitude; however, this variation was not well correlated with the differences in ACh synthesis. The factor(s) in neuronal cell conditioned medium induced a rearrangement of pre-existing receptors at the cell surface, and its action was not dependent on new protein synthesis.

The results of this study are consistent with the idea that one or more receptor aggregation factors secreted by neurons are involved in the organization of neurotransmitter receptors during synapse formation in vivo.
\end{abstract}

Embryonic skeletal muscle fibers at early stages of development are sensitive to acetylcholine (ACh) along their entire length and exhibit an essentially uniform distribution of $\mathrm{ACh}$ receptors in their plasma membranes. With further development, both ACh sensitivity and the distribution of receptors become restricted to the area of the neuromuscular junction (Diamond and Miledi, 1962; Bevan and Steinbach, 1977; Burden, 1977a). This spatial restriction of receptors is followed by a marked increase in the metabolic stability of the recep-

\footnotetext{
'We are grateful to Scott Dubit and Lisa Chang for technical assistance and to Marty Green for manuscript preparation. A. E. S. was the recipient of a Muscular Dystrophy Association Postdoctoral Research Fellowship.

${ }^{2}$ To whom correspondence should be addressed. Present address: Laboratory of Neurophysiology, National Institute of Neurological and Communicative Disorders and Stroke, National Institutes of Health, Bethesda, MD 20205.
}

tors (Chang and Huang, 1975; Berg and Hall, 1975; Devreotes and Fambrough, 1975; Burden, 1977b; Michler and Sakmann, 1980) as well as, in some species, a change in the ion channel properties of the receptors (Michler and Sakmann, 1980). Synaptic localization of ACh sensitivity also has been demonstrated in parasympathetic neurons of the frog interatrial septum (Harris et al., 1971).

Receptor localization to regions of nerve contact has been described in developing systems in vitro. Acetylcholine receptor clusters have been identified at nervemuscle synapses in co-cultures of embryonic chick spinal cord and muscle (Cohen and Fischbach, 1977; Frank and Fischbach, 1979). Rat skeletal muscle cells from the clonal line L6 exhibit increased acetylcholine sensitivity on areas of the membrane where they are in contact with nerve cells from the mouse neuroblastoma clone N18 (Steinbach et al., 1973). In co-cultures of Xenopus embryonic spinal cord or neural tube cells and muscle, ACh 
receptors are redistributed so as to be localized along points of contact between the two cell types (Anderson and Cohen, 1977; Anderson et al., 1977; Cohen and Weldon, 1980).

The mechanisms whereby innervation leads to receptor localization are unknown. It is possible that receptors are synthesized preferentially and inserted at the endplate region in response to nerve contact or to soluble factors released by the nerve. Another possibility, not exclusive of the first, may involve a redistribution of receptors already present in the plasma membrane in response to the influence of the nerve.

Soluble factors which increase the number of $\mathrm{ACh}$ receptors and the number of receptor aggregates on cultured muscle cells have been found in cell-free extracts of fetal rat and chick nervous tissue (Podleski et al., 1978; Jessell et al., 1979). Christian et al. (1978) identified a high molecular weight $\mathrm{ACh}$ receptor aggregation factor in the medium of cultured neuroblastoma $\times$ glioma hybrid cells. That such a factor may be neural specific was suggested by the finding that the aggregation factor was released by the parent neuroblastoma but not the parent glioma cell line. The activity of this factor was independent of new receptor synthesis. If such a factor is operating in vivo, it should be released by embryonic neurons during the period of synaptogenesis. In this study, we present evidence that several types of rat embryonic neurons in cell culture produce a high molecular weight factor which causes the aggregation of $\mathrm{ACh}$ receptors in the plasma membrane of cultured myotubes. This activity appears to be specific to neurons and occurs in the absence of protein synthesis.

\section{Materials and Methods}

Muscle cultures. Rat myotube cultures were prepared by a modification of the methods of Nelson et al. (1976). Minced muscle from the hindlimbs of 20-day-old Sprague-Dawley rat embryos (Taconic Farms, Germantown, NY) was dissociated for $30 \mathrm{~min}$ at $37^{\circ} \mathrm{C}$ in $0.2 \%$ trypsin (three times crystallized and lyophilized; Millipore Corp., Bedford, MA), 0.01\% DNase (Type I, Sigma, St. Louis, MO), and $1 \%$ glucose in calcium- and magnesium-free Dulbecco's phosphate-buffered saline (CMFPBS). Cells were resuspended in 80\% Dulbecco's minimal essential medium (DMEM; Gibco, Grand Island, NY), 10\% fetal calf serum (North American Biologicals, Inc., Miami, FL), and $10 \%$ horse serum. The cell suspension was passed through a Nitex filter (pore size, $120 \mu \mathrm{m}^{2}$ ) to remove large pieces of tissue, incubated for $20 \mathrm{~min}$ at $37^{\circ} \mathrm{C}$ in $100-\mathrm{mm}$ plastic Petri dishes to allow for the preferential adhesion of fibroblasts, and plated in $1.5 \mathrm{ml}$ of the same medium in $35-\mathrm{mm}$ collagen-coated plastic tissue culture dishes (Falcon, Becton-Dickinson, Cockeysville, MD). After 3 to 4 days, the medium was replaced with $90 \%$ DMFM, $10 \%$ horse serum, and $10 \mu \mathrm{M}$ cytosine arabinoside (ara-C, Sigma) to kill dividing cells. Cytosine arabinoside was removed after 2 to 3 days and the cultures were fed twice weekly. Cultures were incubated in a humidified atmosphere with $10 \% \mathrm{CO}_{2}$ and $90 \%$ air at $36^{\circ} \mathrm{C}$.

Sympathetic neuron cultures. Superior cervical ganglia (SCG) were removed from 18- to 20-day-old SpragueDawley rat embryos, cut in pieces, and dissociated for 30 min at $37^{\circ} \mathrm{C}$ in CMF-PBS containing $0.1 \%$ trypsin, $0.01 \%$ DNase, and $1 \%$ glucose. Cells were resuspended in SCG medium (see below). Clumps were removed by low speed centrifugation or by passing the suspension through $\mathrm{Ni}$ tex (pore size, $120 \mu \mathrm{m}^{2}$ ). Cells were plated in $0.5 \mathrm{ml}$ of SCG medium into collagen-coated $16-\mathrm{mm}$ plastic tissue culture wells (Costar, Cambridge, MA) at a density of 8 to $10 \times 10^{4}$ cells/well. Methocel (hydroxypropyl methylcellulose, Dow Chemical Co., Midland, MI) was added to increase the viscosity of the medium and enhance the attachment of neurons to the substrate (Bray, 1970). Medium was replaced every 2 days. "Adrenergic" cultures (SCG-AIR) were grown in SCG medium according to a modification of the method of Mains and Patterson (1973). The SCG medium consisted of L15 (Leibowitz medium, Microbiological Associates, Bethesda, MD) supplemented with $28 \mathrm{mM}$ ( $5 \mathrm{gm} /$ liter) glucose, $36 \mu \mathrm{M}(5 \mathrm{mg} /$ liter) $p$-aminobenzoic acid (Sigma), $0.5 \mu \mathrm{M}(0.4 \mathrm{mg} / \mathrm{liter})$ coenzyme A (Sigma), $0.9 \mathrm{~mm}$ (60 mg/liter) imidazole (Sigma), 5\% fetal calf serum, 5\% rat serum (Microbiological Associates), 0.4 to $0.6 \%$ Methocel, and $100 \mathrm{ng} / \mathrm{ml}$ of nerve growth factor (NGF; kindly supplied by Dr. Gordon Guroff, National Institutes of Health, Bethesda, MD). Cultures were maintained in a humidified air atmosphere at $36^{\circ} \mathrm{C}$. Although non-neuronal cells did not proliferate extensively in medium without sodium bicarbonate, it was sometimes necessary to add $10 \mu \mathrm{M}$ ara-C for 1 to 2 days after the cells had been in culture for 1 week. "Cholinergic" cultures (SCG-CO ${ }_{2}$ ) were prepared in a manner similar to that described for adrenergic cultures with the following exceptions. SCG medium minus NGF was supplemented with $26 \mathrm{~mm}(2.2 \mathrm{gm} / \mathrm{liter})$ sodium bicarbonate and conditioned by incubation with rat myotube cultures. Conditioned medium (CM) then was diluted with fresh medium to give a final concentration of $60 \% \mathrm{CM}$ and supplemented with $100 \mathrm{ng} / \mathrm{ml}$ of NGF. SCG cells were plated in this medium with Methocel to yield cholinergic cultures (Patterson and Chun, 1977). Cytosine arabinoside was added to the cultures 4 to 5 days after plating and removed after 2 days. Cultures prepared in this manner were essentially free of non-neuronal cells (Fig. 1 $a$ ).

SCG glial cultures were obtained by omitting Methocel and NGF from SCG medium. Muscle cultures used for $\mathrm{CM}$, cholinergic neuronal cultures, and glial cultures were maintained in a humidified atmosphere with $5 \% \mathrm{CO}_{2}$ and $95 \%$ air at $36^{\circ} \mathrm{C}$.

Co-culture of rat myotubes and SCG neurons. Muscle cells were prepared as described above. A cell suspension of $7.5 \times 10^{5} \mathrm{SCG}$ neurons in 90\% DMEM, 5\% horse serum, $5 \%$ fetal calf serum, $100 \mathrm{ng} / \mathrm{ml}$ of $\mathrm{NGF}$, and 10 $\mu \mathrm{M}$ ara-C was added to 10 -day muscle cultures and cocultured for a 4-day period.

Dorsal root ganglion cultures. Dorsal root ganglia (DRG) were removed from 16-day-old rat embryos. Cultures were prepared in a manner identical to cholinergic SCG neurons except that they were grown in nonconditioned medium. Cytosine arabinoside was added 4 to 5 days after plating to obtain cultures free of non-neuronal cells (Fig. $1 d$ ).

Cerebellar cultures. Cerebella were removed from 12 to 15-day-old Sprague-Dawley rat embryos and dissociated by vigorous trituration followed by passage 

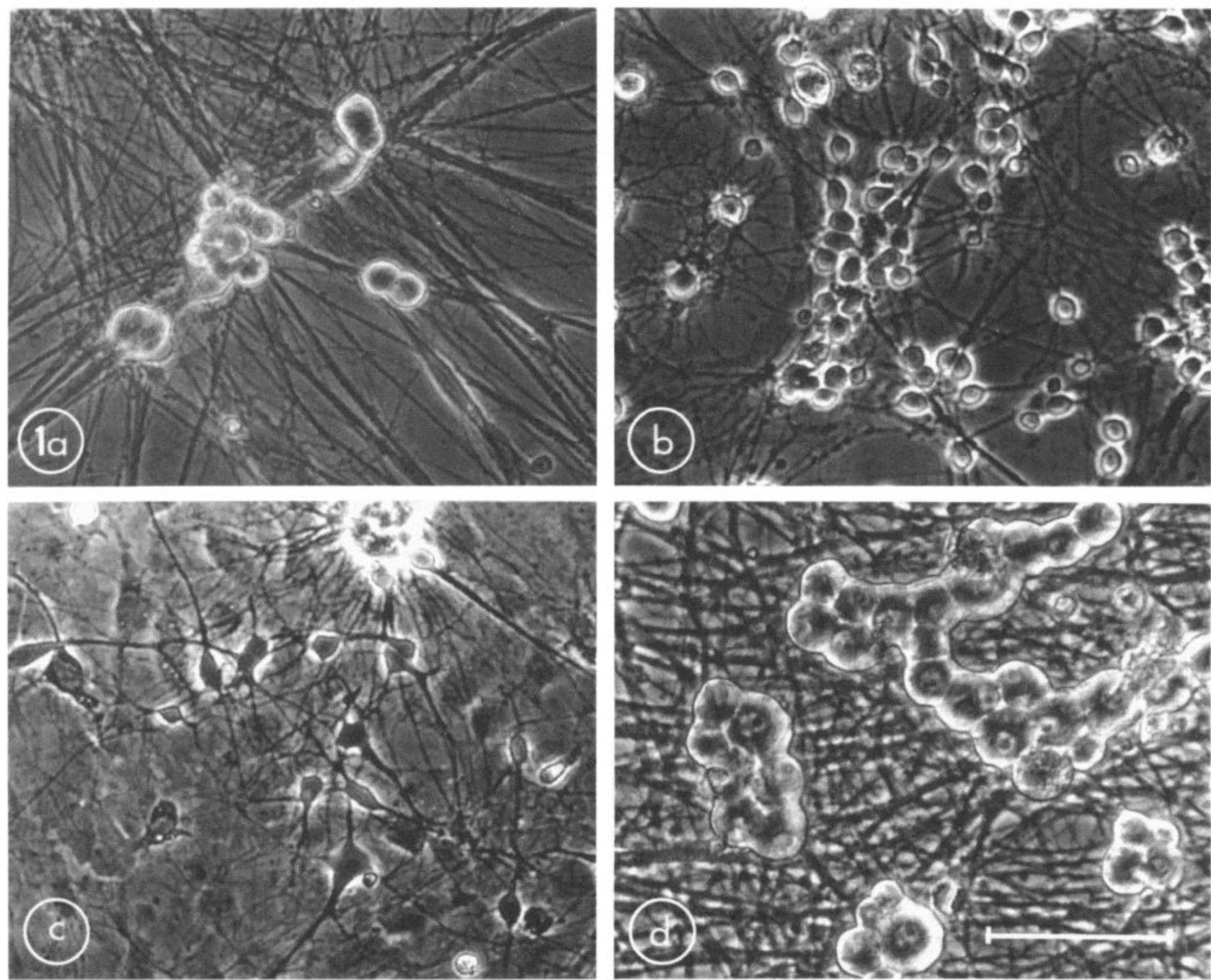

Figure 1. Cultures of dissociated primary neurons from $(a)$ superior cervical ganglia, $(b)$ cerebellum, $(c)$ spinal cord, and $(d)$ dorsal root ganglia, typical of the cultures used as sources of neuronal CM. In $a, b$, and $d$, very few non-neuronal cells are present. These are phase contrast photomicrographs. Bar, $100 \mu \mathrm{m}$.

through a Nitex filter (pore size, $120 \mu \mathrm{m}^{2}$ ). Approximately $5 \times 10^{5}$ cells were plated per collagen-coated $16-\mathrm{mm}$ plastic tissue culture well (Costar or Linbro, Linbro Division, Flow Laboratories, Inc., Hamden, CT) in $0.5 \mathrm{ml}$ of $80 \%$ DMEM, $10 \%$ fetal calf serum, and $10 \%$ horse serum. Medium was supplemented with an additional $31 \mathrm{~mm}$ (5.5 gm/liter) glucose (final glucose concentration, $56 \mathrm{~mm}$ $(10 \mathrm{gm} / \mathrm{liter}))$ and 80 units/liter of insulin (crystalline, bovine pancreas; Sigma) according to Sotelo et al. (1980). After 5 days, the medium was replaced with DMEM containing $10 \%$ horse serum and $10 \mu \mathrm{M}$ ara-C. After 4 to 5 days, cultures were fed the same medium without araC. Cultures were maintained in a humidified atmosphere with $10 \% \mathrm{CO}_{2}$ and $90 \%$ air at $36^{\circ} \mathrm{C}$. A typical culture is shown in Figure $1 b$.

Spinal cord cultures. Spinal cords were removed from 12-day-old Sprague-Dawley rat embryos, stripped of dorsal root ganglia and meninges, and dissociated in CMFPBS containing $0.02 \%$ trypsin and $0.01 \%$ DNase. Cells were resuspended in $80 \%$ DMEM, $10 \%$ horse serum, and $10 \%$ fetal calf serum. The medium was supplemented with $28 \mathrm{~mm}$ (5 gm/liter) glucose and $18 \mathrm{~mm}$ (1.5 gm/liter) sodium bicarbonate (Ransom et al., 1977). Cells were plated in $1.5 \mathrm{ml}$ of medium into $35-\mathrm{mm}$ collagen-coated dishes at a density of $1.2 \times 10^{6}$ cells/dish. After 4 to 5 days, the medium was replaced with $90 \%$ DMEM, $10 \%$ horse serum, $10 \mu_{\mathrm{M}}$ fluorodeoxyuridine (Sigma), and 100 $\mu \mathrm{M}$ uridine (Sigma). The fluorodeoxyuridine was removed after 2 days. A typical culture is shown in Figure $1 c$. Spinal cord glial cultures were obtained by incubating 1week-old cultures with $\mathrm{A}_{2} \mathrm{~B}_{5}$, a neuron-specific cytotoxic antibody (Eisenbarth et al., 1979) in the presence of guinea pig complement (Cappel Laboratories, Inc., Cochranville, PA). Antibody was added under saturating conditions at a final concentration of $7 \mu \mathrm{g} / \mathrm{ml}$. Glial cultures were grown in $90 \%$ DMEM and $10 \%$ horse serum supplemented as above.

Spinal cord cultures enriched for small neurons and containing very low levels of choline acetyltransferase activity were prepared as described elsewhere (Schnaar and Schaffner, 1981) and grown in a manner identical to whole dissociated spinal cord (nonseparated) neuronal cultures. All spinal cord cultures were grown in a humidified atmosphere with $10 \% \mathrm{CO}_{2}$ and $90 \%$ air at $36^{\circ} \mathrm{C}$. 
Other non-neuronal cell cultures. Conditioned medium was obtained from cultures of adult rat skin fibroblasts and adult peritoneum courtesy of Dr. George Eisenbarth, Duke University Medical Center, Durham, NC.

Conditioned medium. Conditioned medium (CM) from neuronal and non-neuronal cell cultures was removed sterilely every 2 days, centrifuged at $1,200 \times g$ for $5 \mathrm{~min}$, decanted, and frozen at $-20^{\circ} \mathrm{C}$. Before application to muscle cultures, CM was thawed, recentrifuged, and pooled. Conditioned medium to be concentrated was pooled and placed in a $50-\mathrm{ml}$ Amicon filtration cell (Amicon Corp., Lexington, MA) fitted with an XM50 membrane (nominal molecular weight cutoff, 50,000). The medium was concentrated at $4^{\circ} \mathrm{C}$ and this process required 2 to $4 \mathrm{hr}$ for each sample. Both the retentates and their respective ultrafiltrates were passed through a $0.45-\mu \mathrm{m}$ Millex filter wetted with medium (Millipore Corp.) and refrigerated until use, usually within $16 \mathrm{hr}$. Serial dilutions of concentrated CM were made by the addition of appropriate volumes of fresh medium.

Bioassay. Conditioned medium was applied to 12-dayold muscle cultures and removed after $24 \mathrm{hr}$. Cultures were rinsed twice for $5 \mathrm{~min}$ in DMEM and $10 \%$ fetal calf serum and stained for $1 \mathrm{hr}$ at $36^{\circ} \mathrm{C}$ with tetramethylrhodamine-labeled $\alpha$-bungarotoxin (TMR- $\alpha \mathrm{BTx}$; kindly supplied by Dr. Zvi Vogel, Weizmann Institute of Science, Rehovot, Israel) in the same medium. Cultures were rinsed for $10 \mathrm{~min}$ in DMEM and $10 \%$ fetal calf serum and twice for $10 \mathrm{~min}$ in DMEM buffered with $25 \mathrm{~mm}$ HEPES (4-(2-hydroxyethyl)-1-piperazine-ethanesulfonic acid, Gibco), pH 7.4, in the absence of serum. Then cultures were fixed for $30 \mathrm{~min}$ in $2 \%$ formaldehyde, $0.1 \mathrm{M}$ sodium phosphate buffer, $\mathrm{pH} 7.4$, at $4^{\circ} \mathrm{C}$, rinsed twice for $30 \mathrm{~min}$ in $0.1 \mathrm{M}$ sodium phosphate buffer at $4^{\circ} \mathrm{C}$, and placed in $80 \%$ ethanol at $-20^{\circ} \mathrm{C}$. Cultures were examined with a Zeiss Photomicroscope II equipped with epi-illumination. Light from an HBO W/4 mercury arc lamp was passed through BP546/9 and KP600 excitation filters and a Kodak 23A barrier filter. The appearance of the myotubes under these conditions is shown in Figure 2. To quantify the effects of CM, each concentration or dilution of CM was added to duplicate cultures. Twenty-five fields (at least 100 myotube segments) in each culture were viewed and the number of fluorescent $\mathrm{ACh}$ receptor aggregates (A) was divided by the number of myotube segments (M). A myotube segment was defined as any continuous length of myotube visible in the field. The length of myotube segments did not change noticeably under the various conditions and cultures were always viewed at the same final magnification. The average A/M of duplicate cultures exposed to $\mathrm{CM}$ was divided by the average A/M of control cultures exposed to fresh medium to give an $\mathrm{A} / \mathrm{M}$ ratio. In almost all cases, duplicate plates gave $\mathrm{A} / \mathrm{M}$ values which differed by $<15 \%$.

Biochemical determinations. Total cell protein in cultures used as sources of CM was determined by a micromodification of the method of Lowry et al. (1951) after washing the cultures three times at $4^{\circ} \mathrm{C}$ with CMF-PBS. Acetylcholine synthesis in the cultures was determined by a modification of the method of Hildebrand et al. (1971). Fifty to $140 \mathrm{nM}\left[{ }^{3} \mathrm{H}\right]$ choline chloride (New England Nuclear, Boston, MA) with a specific activity in the
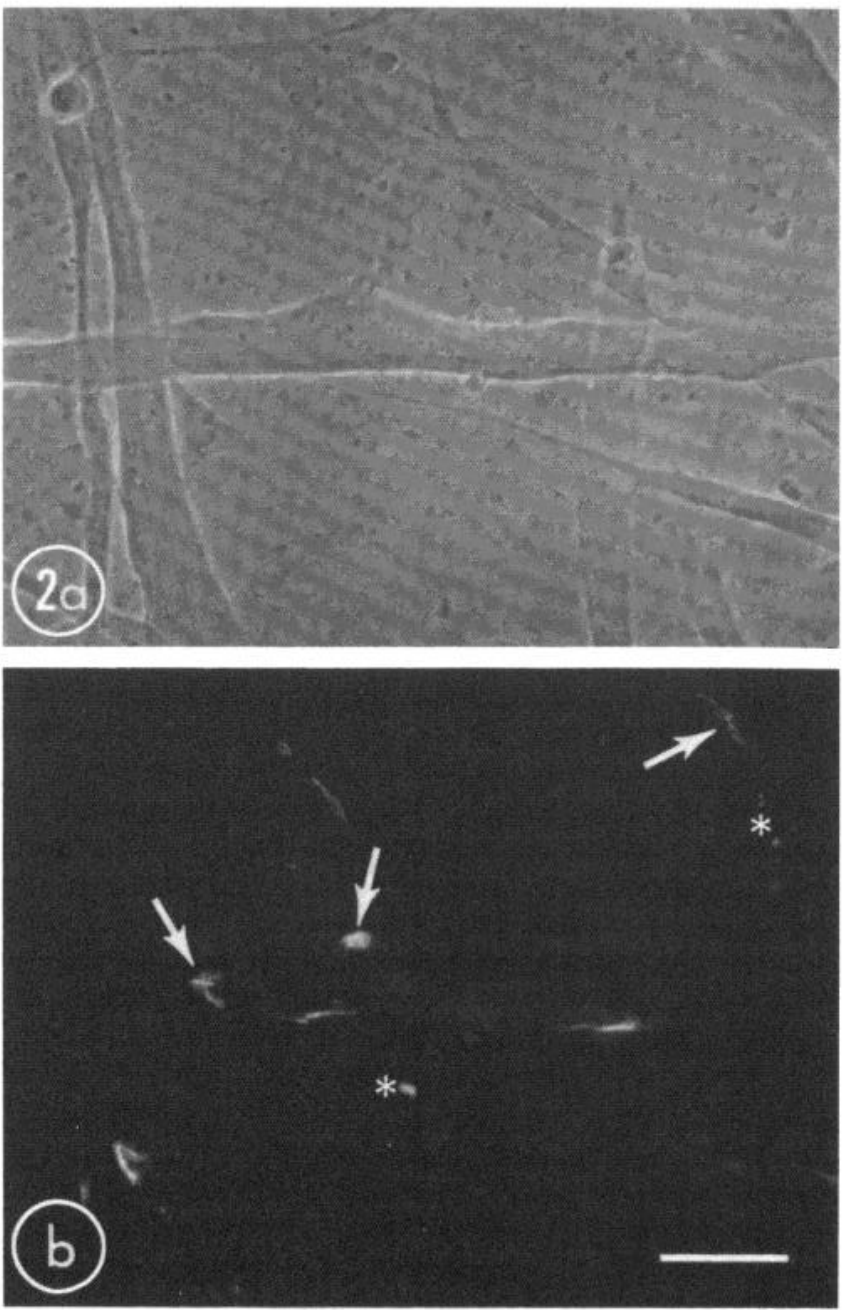

Figure 2. Embryonic rat skeletal myotubes, 12 days in culture, exposed to spinal cord CM for $24 \mathrm{hr}$ and subsequently stained with tetramethylrhodamine $\alpha$-bungarotoxin to reveal the distribuition of ACh receptors. $a$, Phase contrast; $b$, fluorescence photomicrographs. Seven receptor aggregates and nine myotube segments are evident. The arrows indicate examples of three receptor aggregates. The asterisks mark areas where there is fluorescent debris. Bar, $50 \mu \mathrm{m}$.

incubation medium of 0.30 to $1.00 \mathrm{Ci} / \mathrm{mmol}$ was added to the cultures for 16 to $20 \mathrm{hr}$. $\left[{ }^{3} \mathrm{H}\right]$ Acetylcholine was extracted by incubating washed cultures with 0.5 to $1 \mathrm{ml}$ of an ice cold mixture of $85 \%$ acetone, $15 \% 1 \mathrm{~N}$ formic acid at $0^{\circ} \mathrm{C}$ for $10 \mathrm{~min}$. The extract was dried in air and resuspended in $150 \mu \mathrm{l}$ of acetone/formic acid, and $25 \mu \mathrm{l}$ was applied to chromatography paper and subjected to high voltage electrophoresis. The electrophoresis buffer contained $1.5 \mathrm{M}$ acetic acid and $0.75 \mathrm{~m}$ formic acid, $\mathrm{pH}$ 1.8. ACh spots were identified by running a standard of $0.1 \mathrm{M} \mathrm{ACh}$ and $0.1 \mathrm{M}$ choline with each sample and exposing the paper to crystalline iodine vapors. ACh spots were cut out and counted in a liquid scintillation counter.

\section{Results}

Effect of SCG and DRG neurons on ACh receptor aggregation. Rat myotubes co-cultured with SCG neu- 
rons for 4 days exhibited a 5.8 -fold increase in the $\mathrm{A} / \mathrm{M}$ over myotubes cultured in the absence of neurons. To determine if physical contact between nerve and muscle cells was a prerequisite for $\mathrm{ACh}$ receptor (AChR) aggregation, 12-day myotube cultures were incubated for 24 hr with medium which had been conditioned previously by exposure to SCG neuronal cultures (Table I, experiments 1 and 2). Conditioned medium from SCG cultures, grown under adrenergic or cholinergic conditions, elicited increases in the $\mathrm{A} / \mathrm{M}$ of 2.6 and 3.4, respectively. Conditioned medium from SCG glial cultures caused a 3.0-fold decrease in the A/M. Sixty-percent muscle CM, used to induce cholinergic development of SCG neurons, had no effect on the $\mathrm{A} / \mathrm{M}$ ratio nor did fresh medium supplemented with ara-C or NGF. Aggregation activity of SCG $\mathrm{CM}$ from cholinergic cultures was reduced to 1 or control levels after an 8-fold dilution with fresh medium. The inhibitory action of glial CM was lost after a 2-fold dilution with fresh medium. It is possible that the inhibitory effect produced by SCG glial cells could modulate the effect of SCG neurons in vivo. However, in these in vitro studies, both the SCG-AIR and SCG-CO ${ }_{2}$ cultures were virtually free of background cells and the number of glial cells used to make glial CM far exceeded that found in neuronal cultures.

Preliminary results using CM from glia-free DRG neuronal cultures suggested that these neurons did not release an aggregation factor. However, it was possible that the aggregation factor was released in quantities too low to be detected by the bioassay. For this reason, the high molecular weight components of DRG CM were concentrated up to 10-fold by Amicon filtration, serially diluted, and compared to $\mathrm{CM}$ prepared in a similar manner from adrenergic and cholinergic SCG neuronal cultures (Fig. 3; Table I, experiment 3 ). Each $16-\mathrm{mm}$ well contained approximately 0.23 to $0.33 \mathrm{mg}$ of cell protein. Undiluted CM from both types of SCG cultures caused approximately a 4 - to 5 -fold increase in the $\mathrm{A} / \mathrm{M}$. In order to elicit the same increase, DRG CM had to be concentrated 10 -fold. In this study, the $\mathrm{A} / \mathrm{M}$ ratio of cultures exposed to SCG CM approached 1 or control levels only after a 16 -fold dilution of CM. When ACh synthesis in the three types of neuronal cultures was compared, it was evident that, although SCG neurons grown under adrenergic conditions contained about onetenth the amount of $\mathrm{ACh}$ measured in cultures grown under cholinergic conditions, both undiluted CM from adrenergic and cholinergic SCG cultures had comparable aggregating activity. Acetylcholine was not detected in cells cultured from dorsal root ganglia.

Effect of CM from fetal cerebellar cultures. Conditioned medium was collected from cultures of fetal cerebellum and compared to CM from SCG cultures (grown in medium containing sodium bicarbonate) and DRG neuronal cultures (Fig. 4; Table I, experiment 4). CM from both SCG and fetal cerebellar cultures caused a marked increase in the $\mathrm{A} / \mathrm{M}$ at a range of concentrations from 10 times starting material to a dilution of 0.5 . Dorsal root ganglion cell $\mathrm{CM}$, on the other hand, elicited a smaller increase in the $\mathrm{A} / \mathrm{M}$ and only when concentrated 5 and 10 times. It was possible that, at the higher concentrations, high molecular weight constituents in the serum were inducing AChR aggregation. To test this possibility, fresh L15 medium with $10 \%$ serum was concentrated by Amicon filtration and then serially diluted. This medium indeed caused a 2 -fold increase in the $\mathrm{A} / \mathrm{M}$, but only when concentrated 10 times (Fig. 4). Ultrafiltrates from the concentration of DRG, SCG, and fetal cerebellar CM also were tested for aggregating activity (Table I, experiment 4). None of the ultrafiltrates caused an increase in the $\mathrm{A} / \mathrm{M}$, suggesting that aggregating factors smaller than 50,000 daltons were not present in CM from these sources. The ultrafiltrates from SCG $\mathrm{CM}$, in fact, caused a decrease in the $\mathrm{A} / \mathrm{M}$, indicating that lower molecular weight factors present in conditioned medium may inhibit AChR aggregation or cause dispersal of receptor aggregates.

Effect of spinal cord conditioned medium. Since anterior horn cells of the spinal cord normally innervate skeletal muscle, embryonic rat spinal cord cultures were examined for their ability to release aggregation factor. Conditioned medium was collected from cultures of spinal cord cells containing relatively few glial cells and from cultures of spinal cord glia. The glial cultures were depleted of neurons by plating them at low density and allowing the non-neuronal cells, most of which had the morphology of glia (see, for example, Ransom et al., 1977; Raff et al., 1979), to grow to confluency. Spinal cord cells also were separated on a density gradient (Schnaar and Schaffner, 1981) and two fractions containing small (III) and medium size (II) neurons with very little choline acetyltransferase (CAT) activity were grown in culture. Conditioned medium from these two fractions was compared to CM from cultures of spinal cord glia and from cultures of whole dissociated spinal cord cells not separated on a density gradient (Fig. 5; Table I, experiment 5 ). While CM from nonseparated cord cultures elicited a striking increase in the $\mathrm{A} / \mathrm{M}$ ratio, $\mathrm{CM}$ from the two density gradient fractions with low CAT activity had a lesser effect and CM from glial cultures had a very small effect. The small amount of aggregating activity seen at a 5-fold concentration of "glial" cell CM could have been due to the presence of a small number of neurons which remained in the cultures from the initial plating. Therefore, in a second experiment, $\mathrm{CM}$ from nonseparated spinal cord cultures again was compared to $\mathrm{CM}$ from glial cell cultures prepared by the use of $\mathrm{A}_{2} \mathrm{~B}_{5}$, a neuronspecific, cytotoxic antibody (Eisenbarth et al., 1979). After a 30 -min incubation with the antibody, neuronal cell bodies appeared shrunken, while the background cells appeared morphologically unaltered by the antibody. After CM was collected, the cultures were incubated with tetanus toxin which then was visualized by indirect immunofluorescence (Raff et al., 1979). The absence of specific staining suggested that neurons had indeed not survived treatment with the specific cytotoxic antibody and complement. Conditioned medium from glial cultures had very little aggregating activity even when concentrated 5-fold (Table I, experiment 6; Fig. 6). The small increase in the $\mathrm{A} / \mathrm{M}$ seen in concentrated glial CM could be due to a small population of neuroblasts which did not bind tetanus toxin. There is also the possibility that some non-neural elements synthesize an aggregation factor at low levels. Conditioned medium 
TABLE I

The effect of conditioned medium from neuronal and non-neuronal cell cullures on receptor aggregation

\begin{tabular}{|c|c|c|c|c|c|}
\hline $\begin{array}{l}\text { Expt. } \\
\text { No. }\end{array}$ & Source of $C M$ & Rel. Conc. CM & A/M Ratio & $\frac{\text { mg Protein }}{\text { Culture }}$ & $\frac{\mathrm{pmol} \mathrm{ACh}^{\circ}}{\mathrm{mg} \text { Protein }}$ \\
\hline 1. & $\begin{array}{l}\text { SCG-CO } \\
\text { SCG-AIR } \\
\text { SCG glia }\end{array}$ & $\begin{array}{l}1 \\
1 \\
1\end{array}$ & $\begin{array}{l}3.4 \\
2.6 \\
0.3\end{array}$ & $\begin{array}{l}0.13 \\
0.05 \\
0.05\end{array}$ & $\begin{array}{r}2,280 \\
680 \\
20\end{array}$ \\
\hline 2. & $\begin{array}{l}\text { SCG-CO} \\
\text { Rat skin fibroblasts } \\
\text { Rat peritoneum }\end{array}$ & $\begin{array}{l}1 \\
1 \\
1\end{array}$ & $\begin{array}{l}9.6 \\
0.7 \\
0.2\end{array}$ & $\begin{array}{l}0.28 \\
\text { N.D.C } \\
\text { N.D. }\end{array}$ & $\begin{array}{l}1.710 \\
\text { N.D. } \\
\text { N.D. }\end{array}$ \\
\hline 3. & $\begin{array}{l}\text { SCG-CO } \\
\text { SCG-AIR } \\
\text { DRG }\end{array}$ & $\begin{array}{c}1 \\
1 \\
10 \\
5 \\
1 \\
\text { ultrafiltrate }\end{array}$ & $\begin{array}{l}4.9 \\
4.8 \\
4.5 \\
1.9 \\
1.8 \\
1.0\end{array}$ & $\begin{array}{l}0.33 \\
0.23 \\
0.28\end{array}$ & $\begin{array}{r}1,810 \\
230 \\
0\end{array}$ \\
\hline 4. & $\mathrm{SCG}-\mathrm{CO}_{2}$ & $\begin{array}{c}10 \\
5 \\
1 \\
\text { ultrafiltrate }\end{array}$ & $\begin{array}{l}9.0 \\
5.2 \\
4.4 \\
0.3\end{array}$ & 0.21 & 710 \\
\hline & Cerebelium & $\begin{array}{c}10 \\
5 \\
1 \\
\text { ultrafiltrate }\end{array}$ & $\begin{array}{l}8.1 \\
5.3 \\
4.5 \\
0.9\end{array}$ & 0.10 & 0 \\
\hline & DRG & $\begin{array}{c}10 \\
5 \\
1 \\
\text { ultrafiltrate }\end{array}$ & $\begin{array}{l}5.4 \\
3.7 \\
0.7 \\
1.0\end{array}$ & 0.12 & 0 \\
\hline 5. & $\begin{array}{l}\text { Rat spinal cord } \\
\text { Not separated }\end{array}$ & $\begin{array}{l}5 \\
1\end{array}$ & $\begin{array}{l}3.6 \\
3.0\end{array}$ & 0.28 & 12 \\
\hline & \|llow CAT/LDH) ${ }^{d}$ & $\begin{array}{l}5 \\
1\end{array}$ & $\begin{array}{l}1.7 \\
1.8\end{array}$ & 0.12 & 0 \\
\hline & III (low CAT/LDH) ${ }^{\circ}$ & $\begin{array}{l}5 \\
1\end{array}$ & $\begin{array}{l}2.4 \\
1.4\end{array}$ & 0.05 & 0 \\
\hline & Glia & $\begin{array}{l}5 \\
1\end{array}$ & $\begin{array}{l}1.5 \\
1.2\end{array}$ & 0.74 & 0 \\
\hline 6. & $\begin{array}{l}\text { Rat spinal cord } \\
\text { Not separated }\end{array}$ & $\begin{array}{c}5 \\
1 \\
\text { ultrafiltrate }\end{array}$ & $\begin{array}{l}4.3 \\
2.6 \\
1.2\end{array}$ & 0.48 & 48 \\
\hline & Glia & $\begin{array}{c}5 \\
1 \\
\text { ultrafiltrate }\end{array}$ & $\begin{array}{l}1.4 \\
0.8 \\
1.1\end{array}$ & 0.60 & 13 \\
\hline 7. & $\begin{array}{l}\text { Chick spinal cord } \\
\text { I (high CAT/LDH)d } \\
\text { It (low CAT/LDH) } \\
\text { III (low CAT/LDH) }\end{array}$ & $\begin{array}{l}1 \\
1 \\
1\end{array}$ & $\begin{array}{l}2.4 \\
1.3 \\
1.5\end{array}$ & $\begin{array}{l}\text { N.D. } \\
\text { N.D. } \\
\text { N.D. }\end{array}$ & $\begin{array}{l}\text { N.D. } \\
\text { N.D. } \\
\text { N.D. }\end{array}$ \\
\hline
\end{tabular}

a Cultures in experiments 1 to 4 were plated on 16-mm-diameter Costar wells and, in experiments 5 to 7 , on 35-mm-diameter Falcon plates.

${ }^{b}\left[{ }^{3} \mathrm{H}\right]$ Acetylcholine accumulated over an $18-\mathrm{hr}$ period

${ }^{c}$ N.D., not determined.

${ }^{d}$ As determined previously for fractions obtained by Metrizamide density gradient centrifugation (see Schnaar and Schaffner, 1981). Fraction I contains large cells with a high choline acetyltransferase (CAT) to lactate dehydrogenase (LDH) ratio. Fractions II and III contain medium size and small cells, respectively, and both fractions have a low CAT to IDH ratio. 


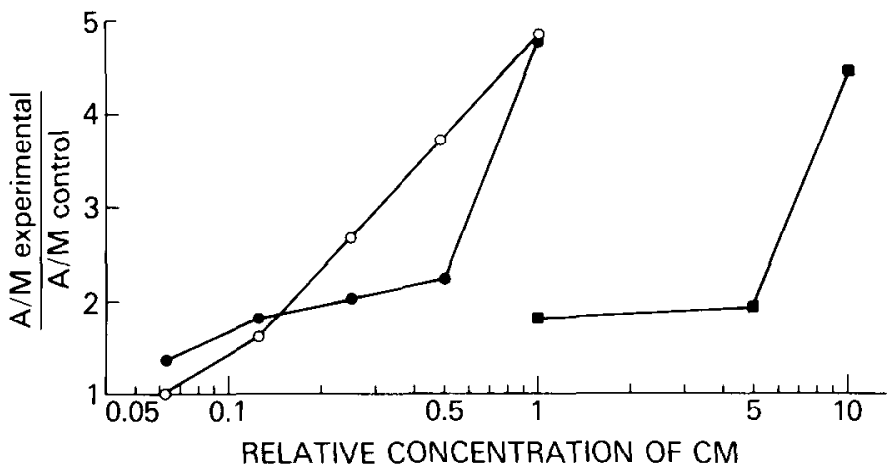

Figure 3. The ACh receptor aggregating activity of original strength and diluted $\mathrm{CM}$ from cholinergic $\left(\mathrm{SCG}-\mathrm{CO}_{2}, \mathrm{O}\right)$ and adrenergic (SCG-AIR, O) SCG neuronal cultures compared with concentrated CM from DRG neuronal cultures ( $\square$ ). The $\mathrm{A} / \mathrm{M}$ is defined as the number of $\mathrm{ACh}$ receptor aggregates per myotube segment. $A / M$ experimental $/ A / M$ control is referred to in the text as the $A / M$ ratio. Each data point represents the average $\mathrm{A} / \mathrm{M}$ of duplicate $\mathrm{CM}$-treated cultures divided by the $\mathrm{A} / \mathrm{M}$ of duplicate cultures treated with the appropriate nonconditioned medium. The value of the average $A / M$ in SCG medium without sodium bicarbonate (SCG-AIR) was 0.42 and, in SCG medium with sodium bicarbonate (SCG-CO $\mathrm{CO}_{2}, \mathrm{DRG}$ ), was 0.55 .

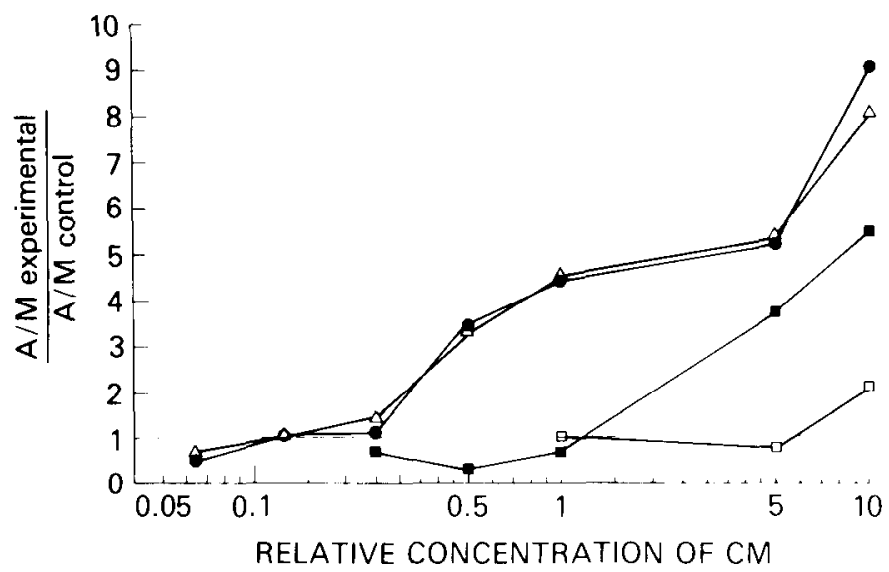

Figure 4. The ACh receptor aggregating activity of concentrated and diluted CM from SCG neuronal cultures (O), DRG neuronal cultures $(\boldsymbol{D})$, and cerebellar neuronal cultures $(\triangle)$. The effect of concentrated, fresh L15 medium with $10 \%$ serum ( $\square$ ) is shown also. In this experiment, SCG cultures were grown with nonconditioned bicarbonate supplemented medium. The value of the average $A / M$ in cultures exposed to the appropriate nonconditioned medium was 0.13 (SCG and DRG) and 0.09 (cerebellum). The A/M ratio of control cultures is defined as 1 (dashed line).

from nonseparated spinal cord cultures, on the other hand, produced a marked increase in the $\mathrm{A} / \mathrm{M}$ even at a dilution of 0.5 times starting material (Table I, experiments 5 and 6; Fig. 6). No activity was detected in the ultrafiltrates after concentration of either glial or neuronal CM.

Conditioned medium from chick spinal cord cells separated on gradients also was tested (Table I, experiment 7). A fraction enriched for large neurons with high levels of CAT activity (I) elicited a 2.4-fold increase in the $\mathrm{A} / \mathrm{M}$ of rat myotube cultures. Conditioned medium from

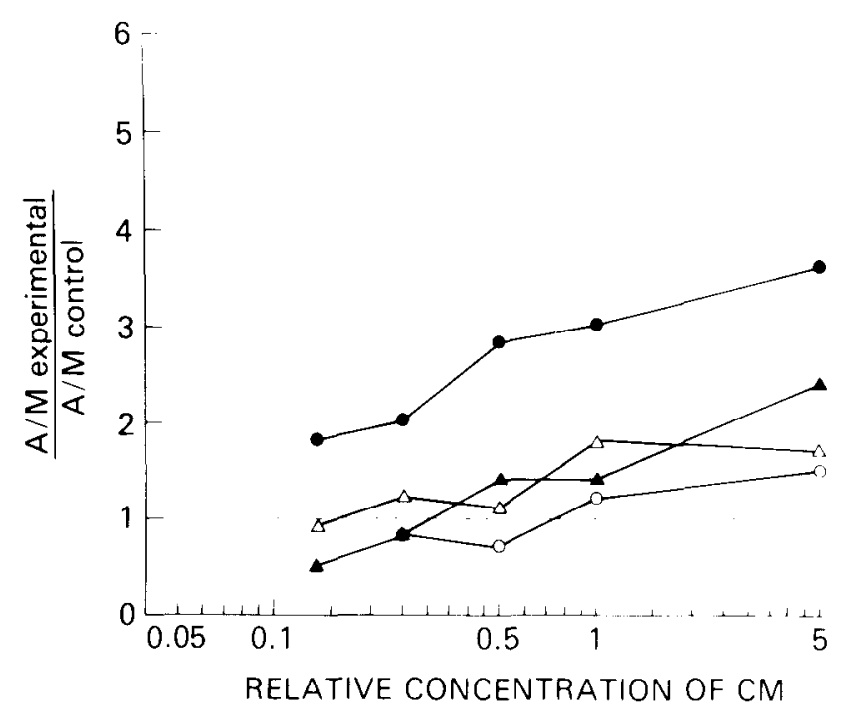

Figure 5. The ACh receptor aggregating activity of concentrated and diluted CM from cell cultures of nonseparated spinal cord (O), spinal cord glia (O), and cultures of small (A) and medium size $(\Delta)$ spinal cord neurons. Small and medium size neurons were obtained by density gradient centrifugation of whole, dissociated spinal cord. These neurons contain very little CAT activity as determined previously (Schnaar and Schaffner, 1981). Glial cultures were obtained by low density plating of dissociated spinal cord cells. The value of the average $A / M$ in cultures exposed to nonconditioned medium was 0.70 .

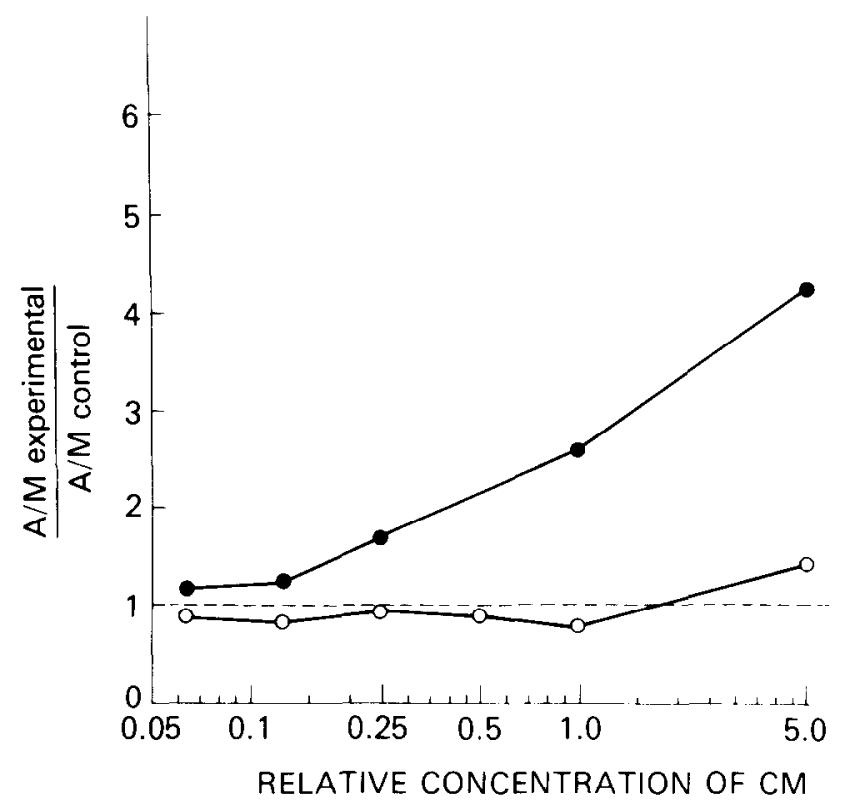

Figure 6. The ACh receptor aggregating activity of concentrated and diluted CM from cell cultures of nonseparated spinal cord (O) and spinal cord glia $(O)$. Glial cultures were obtained by incubating spinal cord cultures with $\mathrm{A}_{2} \mathrm{~B}_{5}$, a neuron-specific, cytotoxic antibody in the presence of complement. The value of the average $\mathrm{A} / \mathrm{M}$ in cultures exposed to nonconditioned medium was 0.77 .

two fractions with smaller neurons and negligible CAT activity (II and III) caused increases in the A/M of 1.3and 1.5-fold, respectively.

Effects of other non-neuronal cell CM. Two additional 
sources of non-neuronal cell CM were tested for AChR aggregating activity (Table I, experiment 2). These included CM from cultures of rat skin fibroblasts and rat peritoneum. Conditioned medium from fibroblast cultures decreased the $\mathrm{A} / \mathrm{M}$, while $\mathrm{CM}$ from peritoneal cultures had no effect.

Morphology of AChR aggregates. There did not appear to be a significant difference in the size of aggregates formed in the presence of CM and those which spontaneously appeared on myotubes from control cultures. In both cases, "patch" aggregates (those seen on the bottom surface of myotubes in contact with the culture dish) were visible, but more aggregates appeared on the sides of myotubes exposed to CM.

Mechanism of action of the aggregation factor. To determine whether the soluble factor released by SCG and spinal cord neurons aggregated AChRs already present in the cell membrane, myotube cultures were labeled with TMR- $\alpha$ BTx $1 \mathrm{hr}$ before the application of CM. In this way, receptors inserted into the plasma membrane during $\mathrm{CM}$ treatment would not be labeled. The A/M and $\mathrm{A} / \mathrm{M}$ ratio of the prelabeled cultures were compared to those of cultures labeled after the 24-hr incubation period (postlabeled). In both cases, similar A/M ratios were seen (Table II). This result indicated that the factor was causing aggregation of AChRs already present on the cell surface and that its action did not depend directly upon the insertion of new receptors.

To determine whether protein synthesis was necessary for aggregation, myotube cultures were incubated with $100 \mu \mathrm{g} / \mathrm{ml}$ of cycloheximide during the $24-\mathrm{hr}$ exposure to $\mathrm{CM}$. It should first be noted that the $\mathrm{A} / \mathrm{M}$ of control cultures exposed to cycloheximide alone was lower than the $\mathrm{A} / \mathrm{M}$ of controls not exposed to the protein synthesis inhibitor. Cycloheximide may have caused dispersal of $\mathrm{AChR}$ aggregates or reduced the total number of receptors as a result of degradation without replacement. The $\mathrm{A} / \mathrm{M}$ of cultures incubated with both cycloheximide and $\mathrm{CM}$ was similar to the $\mathrm{A} / \mathrm{M}$ in prelabeled or postlabeled cultures (Table II). This resulted in a much higher A/M ratio for cultures exposed to both cycloheximide and $\mathrm{CM}$, suggesting that CM may have stabilized AChRs or AChR aggregates in the presence of cycloheximide. Christian et

TABLE II

Mechanism of action of the aggregating factor(s) in conditioned medium

\begin{tabular}{|c|c|c|c|c|}
\hline & \multicolumn{2}{|c|}{ Experiment 1: SCG-AIR } & \multicolumn{2}{|c|}{$\begin{array}{l}\text { Experiment 2: Spinal } \\
\text { Cord }\end{array}$} \\
\hline & $\mathrm{A} / \mathrm{M}$ & A/M Ratio & $\mathrm{A} / \mathbf{M}$ & A/M Ratio \\
\hline Postlabeled & 1.21 & 2.1 & 2.62 & 3.4 \\
\hline Control & 0.57 & & 0.77 & \\
\hline Prelabeled & 0.92 & 2.1 & 2.82 & $3.7^{a}$ \\
\hline Control & 0.44 & & & \\
\hline Cycloheximide & 1.04 & 6.9 & 3.09 & 5.5 \\
\hline Control & 0.15 & & 0.56 & \\
\hline
\end{tabular}

"This value is based on the postlabeled control value. Since the $\mathrm{A} / \mathrm{M}$ in prelabeled controls tends to be less than postlabeled controls, probably due to some receptor turnover, this value would be a conservative estimate of the $\Lambda / M$ ratio. Each value for $A / M$ is an average of the $\mathrm{A} / \mathrm{M}$ in duplicate cultures. al. (1980) found that CM from neuroblastoma cells slowed the rate of AChR degradation and increased the rate of AChR insertion into myotube membranes. Clearly, blockade of protein synthesis does not block the effect of CM.

\section{Discussion}

In this study, we have demonstrated that conditioned medium from cultures of embryonic mammalian neurons contains an AChR aggregation factor. The phenomena of factor production by neurons and receptor aggregation in the muscle are not dependent on physical contact between the two cell types since medium conditioned by neuronal cultures elicits the effect. The aggregation factor appears to be neuron specific since none of the nonneuronal cells tested caused more than a barely detectable increase in the $\mathrm{A} / \mathrm{M}$. In fact, several of these cell types caused a decrease in the $\mathrm{A} / \mathrm{M}$, indicating that they may release factors which inhibit aggregation or possibly disperse or destabilize AChR aggregates. The presence of an $\mathrm{AChR}$ aggregation factor in the $\mathrm{CM}$ from neuronal cultures is most simply explained by synthesis and release of the factor by the neurons. However, since serum was present in the culture medium used in the experiments reported here, it is possible that the factor was produced by the action of neurons on one or more high molecular weight serum components. In preliminary experiments (data not shown), marked AChR aggregating activity was detected in medium from SCG neuronal cultures maintained for 1 month in the absence of serum, suggesting that the factor is released by neurons and acts independently of serum components.

It appears that several types of embryonic neurons, to varying degrees, are able to generate a factor which aggregates AChRs. However, the relationship between this ability and the expression of cholinergic properties is not clear. Conditioned medium from DRG neuronal cultures has low aggregating activity which is clearly detected only after concentrating the medium 10-fold. The presence of ACh, ACh esterase, and CAT in low amounts has been demonstrated in dorsal root ganglia (Phillis, 1970; Karczmar et al., 1980) of vertebrates, especially neonates. However, electrophysiological and neuropharmacological studies indicate that spinal ganglia are not cholinergic and that these "cholinergic" substances may play a role not related to neurotransmission. Synaptic connections have not been detected in co-cultures of DRG neurons and muscle (Fischbach, 1972; Obata, 1977). SCG neurons grown under adrenergic conditions synthesize small but measurable amounts of ACh. Conditioned medium from these cultures elicited an effect on a per milligram of (cell) protein basis comparable to CM from SCG neuronal cultures which were grown under cholinergic conditions and synthesized 10 times as much ACh. It is interesting to note that, in co-cultures of L6 myotubes and N18 neuroblastoma cells, localization of AChR on the muscle cells occurs in the absence of ACh release by the nerve (Steinbach et al., 1973). Synthesis and release of ACh by sympathetic neurons both in vivo and in vitro have been well documented (DeFeudis, 1974; Krnjević, 1974; Patterson and Chun, 1977; Burnstock, 1981). Conditioned medium from fetal cerebellar neuronal cultures also has a marked aggregating 
effect. The reasons for the marked aggregating activity found in the CM of a system generally thought to be noncholinergic are not clear. Only very low levels of CAT activity have been found in the cerebellar cortex and synthesis of ACh has not been demonstrated unequivocally in vivo (DeFeudis, 1974; Krnjević, 1974). Pharmacological studies indicate that a proportion of the fibers of deep nuclear neurons in the cat cerebellum may be cholinergic (Phillis, 1970; DeFeudis, 1974); however; synaptic connections have not been detected in vitro between cerebellar neurons and skeletal muscle (Obata, 1977). Since the cerebella are removed from embryos at a time when this portion of the brain is relatively undeveloped, with the different neuronal populations undergoing mitosis, migration, and differentiation (Jacobson, 1978), it is possible that some of the cells are neuroblasts and consequently are pleuripotent. It would be interesting to determine whether other neurotransmitter receptor types, such as those found on the cells innervated by cerebellar neurons, would be induced to aggregate by cerebellar or other neuronal CM. Significant aggregating activity also was detected in spinal cord cultures. The spinal cord is the source of the motoneurons which normally innervate skeletal muscle and provides a classic model of cholinergic neurotransmission.

It is interesting to compare the results found in mammalian systems with the recent work on the co-culture of skeletal muscle with different nerve cell tissue types in the chick (Hooisma et al., 1980) and amphibian (Cohen and Weldon, 1980). In both nonmammalian systems, coculture of muscle and spinal cord explants induced the formation of AChR aggregates. In Xenopus, many of the newly formed aggregates were localized to the areas of nerve-muscle contact. However, in both species, when muscle cells were co-cultured with explants from dorsal root ganglia or superior cervical ganglia, very few aggregates were formed, if any, and the aggregates were found most often at noncontacted areas of the muscle membrane. The failure of DRG neurons to induce receptor aggregation in co-cultures might be explained by the relatively low aggregation activity found in our system. It is not clear why SCG neurons from the chick or amphibian were not able to induce AChR aggregation in co-cultures, while SCG neurons from the rat are effective. In this regard, it may be significant that SCG neurons from the rat are capable of forming synapses with cultured rat skeletal myotubes (Nurse and O'Lague, 1975). However, there is no evidence for the formation of functional synapses between chick or amphibian SCG neurons and muscle (Grinnell and Rheuben, 1979; Obata, 1977). It is possible that the capacity to produce factors capable of inducing $\mathrm{ACh}$ receptor aggregation is more widespread among mammalian than amphibian or avian embryonic neurons. Additionally, muscle cells from certain species may have more stringent requirements for the induction of AChR aggregation. A third possibility is that different culture conditions for the various vertebrate systems are more or less conducive to synthesis and release of neuronal aggregation factors or affect the muscle's response to such factors. It is also possible that the aggregation factor detected in vertebrate neuronal cultures has functions unrelated to the establishment of cholinergic synapses.
The characteristics of the AChR aggregation factor from primary cultures of embryonic neurons appear very similar to those described in the neuroblastoma $\times$ glioma hybrid cell line NG108-15 (Christian et al., 1978). The results of Amicon filtration of primary neuronal cell CM suggested that the factor has a molecular weight greater than 50,000 since none of the ultrafiltrates tested had any aggregating activity, and the activity was concentrated quantitatively above the filter. The macromolecules responsible for aggregation do not appear to take the form of large particulates because activity passes through a $0.2-\mu \mathrm{m}$ Millipore filter. Preliminary biochemical characterization of the factor produced by NG108-15 cells suggested that it had a molecular weight of 150,000 to 200,000 (Bauer et al., 1981). The time course of aggregation also appears to be similar in the two systems. Undiluted CM from NG108-15 cell cultures and primary neuronal cell cultures elicits greater than a 2 -fold increase in the $\mathrm{A} / \mathrm{M}$ of myotube cultures within $24 \mathrm{hr}$. Conditioned media from hybrid cells, SCG neurons, and spinal cord neurons are all able to effect aggregation in the absence of protein synthesis and appear to cause aggregation of receptors already present on the muscle cell surface.

These findings differ in several aspects from the properties described for an aggregation factor isolated by Jessell et al. (1979) from chick neural tissue. This factor had a molecular weight of about 2,000 and required an incubation period of several days to cause an increase in the number of receptor aggregates. This increase was accompanied, with approximately the same time course, by a 4.8 -fold increase in the number of $\alpha$ BTx binding sites. In the present study, the possibility of a long term effect of neuronal CM on receptor number was not tested. However, it was shown recently that CM from NG108-15 cell cultures contains one or more factors which decrease the turnover rate and increase the rate of ACh receptor insertion in cultured rat myotubes (Christian et al., 1980; Hasegawa et al., 1980). Podleski et al. (1978) have reported a factor or factors with a molecular weight greater than 100,000 from rat neural tissues which increased both receptor density and aggregates on L6 myotubes. Thus, it is likely that neurons and other cells from neural tissues produce more than one factor which can influence both the number and distribution of ACh receptors. The ability of primary neurons and neuronal cell lines to release soluble factors which aggregate and, in some cases, stabilize AChRs on muscle suggests that these substances may play an integral role in the initiation and maintenance of functional synaptic connections during development. Further work will be required to demonstrate the role of receptor aggregation factors in vivo.

\section{References}

Anderson, M. J., and M. W. Cohen (1977) Nerve-induced and spontaneous redistribution of acetylcholine receptors on cultured muscle cells. J. Physiol. (Lond.) 268: 757-773.

Anderson, M. J., M. W. Cohen, and E. Zorychta (1977) Effects of innervation on the distribution of acetylcholine receptors on cultured muscle cells. J. Physiol. (Lond.) 268: 731-756.

Bauer, H. C., M. P. Daniels, P. A. Pudimat, L. Jacques, H. Sugiyama, and C. N. Christian (1981) Characterization and partial purification of a neuronal factor which increases acetylcholine receptor aggregation on cultured muscle cells. 
Brain Res. 209: 395-405.

Berg, D. K., and Z. W. Hall (1975) Loss of $\alpha$-bungarotoxin from junctional and extrajunctional receptors in rat diaphragm muscle in vivo and in organ culture. J. Physiol. (Lond.) 252: 771-789.

Bevan, S., and J. H. Steinbach (1977) The distribution of $\alpha$ bungarotoxin binding sites on mammalian skeletal muscle developing in vivo. J. Physiol. (Lond.) 267: 195-213.

Bray, D. (1970) Surface movements during the growth of single explanted neurons. Proc. Natl. Acad. Sci. U. S. A. 65: 905-910.

Burden, S. (1977a) Development of the neuromuscular junction in the chick embryo: The number, distribution and stability of acetylcholine receptors. Dev. Biol. 57: 317-329.

Burden, S. (1977b) Acetylcholine receptors at the neuromuscular junction: Developmental change in receptor turnover. Dev. Biol. 61: 79-85.

Burnstock, G. (1981) Neurotransmitters and trophic factors in the autonomic nervous system. J. Physiol. (Lond.) 313: 1-35.

Chang, C. C., and M. C. Huang (1975) Turnover of junctional and extrajunctional acetylcholine receptors of the rat diaphragm. Nature 253: 643-644.

Christian, C. N., M. P. Daniels, H. Sugiyama, Z. Vogel, L. Jacques, and P. G. Nelson (1978) A factor from neurons increases the number of acetylcholine receptor aggregates on cultured muscle cells. Proc. Natl. Acad. Sci. U. S. A. 75: 4011-4015.

Christian, C. N., H. C. Bauer, and S. Hasegawa (1980) Neuronal regulation of muscle cell acetylcholine receptor distribution, stability and concentration. In Cellular Analogues of Conditioning and Neural Plasticity, O. Fehér and F. Jóo, eds., pp. 275-283, Pergamon Press, Elmsford, NY.

Cohen, M. W., and P. R. Weldon (1980) Localization of acetylcholine receptors and synaptic ultrastructure at nerve-muscle contacts in culture: Dependence on nerve type. J. Cell Biol. 86: 388-401.

Cohen, S. A., and G. D. Fischbach (1977) Clusters of acetylcholine receptors located at identified nerve-muscle synapses in vitro. Dev. Biol. 59: 24-38.

Crain, S. M. (1976) Neurophysiologic Studies in Tissue Culture, Raven Press, New York.

DeFeudis, F. V. (1974) Central Cholinergic Systems and Behavior, Academic Press, New York.

Devreotes, P. N., and D. M. Fambrough (1975) Acetylcholine receptor turnover in membranes of developing muscle fibers. J. Cell Biol. 65: 335-358.

Diamond, J., and R. Miledi (1962) A study of foetal and newborn rat muscle fibers. J. Physiol. (Lond.) 162: 393-408.

Eisenbarth, G. S., F. S. Walsh, and M. Nirenberg (1979) Monoclonal antibody to a plasma membrane antigen of neurons. Proc. Natl. Acad. Sci. U. S. A. 76: 4913-4917.

Fischbach, G. D. (1972) Synapse formation between dissociated nerve and muscle cells in low density cultures. Dev. Biol. 28: 407-429.

Frank, E., and G. D. Fischbach (1979) Early events in neuromuscular junction formation in vitro. J. Cell Biol. 83: 143-158.

Grinnell, A. D., and M. B. Rheuben (1979) The physiology, pharmacology and trophic effectiveness of synapses formed by autonomic preganglionic nerves on frog skeletal muscle. J. Physiol. (Lond.) 289: 219-240.

Harris, A. J., S. W. Kuffler, and M. J. Dennis (1971) Differential chemosensitivity of synaptic and extrasynaptic areas on the neuronal surface membrane in parasympathetic neurons of the frog, tested by microapplication of acetylcholine. Proc. R. Soc. Lond. (Biol.) 177: 541-553.

Hasegawa, S., H. C. Bauer, and C. N. Christian (1980) Effects of neuronal cell factors on kinetics and aggregation of cultured rat muscle acetylcholine receptors. Soc. Neurosci. Abstr. 6: 375 .

Hildebrand, J. G., D. L. Barker, E. Herbert, and E. A. Kravitz (1971) Screening for neurotransmitters: A rapid radiochemi- cal procedure. J. Neurobiol. 2: 231-246.

Hooisma, J., A. J. M. Blom, T. Magchielse, H. Muijser, and W. F. Stevens (1980) Can humoral factors induce acetylcholinereceptor aggregates in cultured muscle cells otherwise free of aggregates? Soc. Neurosci. Abstr. 6: 375.

Jacobson, M. (1978) Developmental Neurobiology, Plenum Press, New York.

Jessell, T. M., R. E. Siegel, and G. D. Fischbach (1979) Induction of acetylcholine receptors on cultured skeletal muscle by a factor extracted from brain and spinal cord. Proc. Natl. Acad. Sci. U. S. A. 76: 5397-5401.

Karzcmar, A. G., S. Nishi, S. Minota, and G. Kindel (1980) Electrophysiology, acetylcholine and acetylcholinesterase of immature spinal ganglia of the rabbit. Gen. Pharmacol. 11: 127-134.

Krnjević, K. (1974) Chemical nature of synaptic transmission in vertebrates. Physiol. Rev. 54: 418-540.

Lowry, O. H., N. J. Rosebrough, A. L. Farr, and R. J. Randall (1951) Protein measurement with the Folin phenol reagent. J. Biol. Chem. 193: 265-275.

Mains, R. E., and P. H. Patterson (1973) Primary cultures of dissociated sympathetic neurons. I. Establishment of longterm growth in culture and studies of differentiated properties. J. Cell Biol. 59: 329-345.

Michler, A., and B. Sakmann (1980) Receptor stability and channel conversion in the subsynaptic membrane of the developing mammalian neuromuscular junction. Dev. Biol. 80: 1-17.

Nelson, P., C. Christian, and M. Nirenberg (1976) Synapse formation between clonal neuroblastoma $\times$ glioma hybrid cells and striated muscle cells. Proc. Natl. Acad. Sci. U. S. A. 73: $123-127$.

Nurse, C. A., and P. H. O'Lague (1975) Formation of cholinergic synapses between dissociated sympathetic neurons and skeletal myotubes of the rat in cell culture. Proc. Natl. Acad. Sci. U. S. A. 72: 1955-1959.

Obata, K. (1977) Development of neuromuscular transmission in culture with a variety of neurons and in the presence of cholinergic substances and tetrodotoxin. Brain Res. 119: 141-153.

Patterson, P. H., and L. L. Y. Chun (1977) The induction of acetylcholine synthesis in primary cultures of dissociated rat sympathetic neurons. I. Effects of conditioned medium. Dev. Biol. 56: 263-280.

Phillis, J. D. (1970) The Pharmacology of Synapses, Pergamon Press, Elmford, NY.

Podleski, T. R., D. Axelrod, P. Ravdin, I. Greenberg, M. M. Johnson, and M. M. Salpeter (1978) Nerve extract induces increase and redistribution of acetylcholine receptors on cloned muscle cells. Proc. Natl. Acad. Sci. U. S. A. 75 . 2035-2039.

Raff, M. C., K. L. Fields, S. Hakomori, R. Mirsky, R. Pruss, and J. Winter (1979) Cell-type-specific markers for distinguishing and studying neurons and the major classes of glial cells in culture. Brain Res. 174: 283-308.

Ransom, B. R., E. Neale, M. Henkart, P. N. Bullock, and P. G. Nelson (1977) Mouse spinal cord in cell culture. I. Morphology and intrinsic neuronal electrophysiologic properties. J. Neurophysiol. 40: 1132-1150.

Schnaar, R. L., and A. E. Schaffner (1981) Separation of cell types from embryonic chicken and rat spinal cord: Characterization of motoneuron-enriched fractions. J. Neurosci. 1: 204-217.

Sotelo, J., C. J. Gibbs, Jr., D. C. Gajdusek, B. H. Toh, and M. Wurth (1980) Method for preparing cultures of central neurons: Cytochemical and immunochemical studies. Proc. Natl. Acad. Sci. U. S. A. 77: 653-657.

Steinbach, J. H., A. J. Harris, J. Patrick, D. Schubert, and S. Heinemann (1973) Nerve-muscle interaction in vitro. Role of acetylcholine. J. Gen. Physiol. 62: 255-270. 